\title{
Interpretation of zircon coronae textures from metapelitic granulites of the Ivrea-Verbano Zone, northern Italy: two-stage decomposition of Fe-Ti oxides
}

\author{
Elizaveta Kovaleva ${ }^{1,2}$, Håkon O. Austrheim ${ }^{3}$, and Urs S. Klötzli ${ }^{2}$ \\ ${ }^{1}$ Department of Geology, University of the Free State, Bloemfontein, 9300, 205 Nelson Mandela Drive, \\ Free State, South Africa \\ ${ }^{2}$ Department of Lithospheric Research, Faculty of Earth Sciences, Geography and Astronomy, University of Vienna, \\ Althanstrasse 14, Vienna, 1090, Austria \\ ${ }^{3}$ Section of Physics of Geological processes, Department of Geoscience, University of Oslo, Oslo, 0316, Norway
}

Correspondence to: Elizaveta Kovaleva (kovalevae@ufs.ac.za)

Received: 5 April 2017 - Discussion started: 16 May 2017

Revised: 15 June 2017 - Accepted: 19 June 2017 - Published: 25 July 2017

\begin{abstract}
In this study, we report the occurrence of zircon coronae textures in metapelitic granulites of the IvreaVerbano Zone. Unusual zircon textures are spatially associated with Fe-Ti oxides and occur as (1) vermicular-shaped aggregates 50-200 $\mu \mathrm{m}$ long and 5-20 $\mu \mathrm{m}$ thick and as (2) zircon coronae and fine-grained chains, hundreds of micrometers long and $\leq 1 \mu \mathrm{m}$ thick, spatially associated with the larger zircon grains. Formation of such textures is a result of zircon precipitation during cooling after peak metamorphic conditions, which involved: (1) decomposition of Zr-rich ilmenite to Zr-bearing rutile, and formation of the vermicular-shaped zircon during retrograde metamorphism and hydration; and (2) recrystallization of $\mathrm{Zr}$-bearing rutile to Zr-depleted rutile intergrown with quartz, and precipitation of the submicron-thick zircon coronae during further exhumation and cooling. We also observed hat-shaped grains that are composed of preexisting zircon overgrown by zircon coronae during stage (2). Formation of vermicular zircon (1) preceded ductile and brittle deformation of the host rock, as vermicular zircon is found both plastically and cataclastically deformed. Formation of thin zircon coronae (2) was coeval with, or immediately after, brittle deformation as coronae are found to fill fractures in the host rock. The latter is evidence of local, fluid-aided mobility of Zr. This study demonstrates that metamorphic zircon can nucleate and grow as a result of hydration reactions and mineral breakdown during cooling after granulite-facies metamorphism. Zircon coronae tex-
\end{abstract}

tures indicate metamorphic reactions in the host rock and establish the direction of the reaction front.

\section{Introduction}

\subsection{Growth of metamorphic zircon}

Growth of zircon during metamorphism is described in a variety of lithologies and can occur at different metamorphic grades, from high- (e.g., Fraser et al., 1997, 2004; Degeling et al., 2001; Möller et al., 2003; Wu et al., 2006; Harley et al., 2007; Zhao et al., 2015) to low-temperature metamorphism, including low-temperature hydrothermal reactions (e.g., Dempster et al., 2004, 2008; Rasmussen, 2005; Hay and Dempster, 2009; Hay et al., 2010; Kohn et al., 2015). Growth and new precipitation of zircon has been traced under temperatures as low as $250^{\circ} \mathrm{C}$ (Rasmussen, 2005). Metamorphic zircon can (a) precipitate from fluid or melt (e.g., Rasmussen, 2005; Kohn et al., 2015), (b) can result from breakdown of Zr-bearing phases (major or accessory) (e.g., Davidson and van Breemen, 1988; Fraser et al., 1997, 2004; Degeling et al., 2001), or (c) can exsolve from Zr-bearing phases (e.g., Bingen et al., 2001; Tomkins et al., 2007).

a. New metamorphic zircon precipitates during exhumation and cooling of the host rock (Rasmussen, 2005; Kohn et al., 2015) as a result of partial or complete 
dissolution of preexisting zircon (e.g., Dempster et al., 2008) in partial melt or metamorphic fluid during hightemperature metamorphism (Ewing et al., 2014). Solubility of zircon in most natural fluids is very low (Tromans, 2006); thus, zircon dissolution models mostly describe interactions with the melt (e.g., Harrison and Watson, 1983; Watson and Harrison, 1983). However, under high (prograde) temperatures and in fluids of favorable composition, zircon can be dissolved without melt involvement (e.g., Rubatto et al., 2008; Hay and Dempster, 2009; Hay et al., 2010; Ewing et al., 2014; Kohn et al., 2015).

b. Zircon growth and overgrowth formation during cooling stage and/or retrograde metamorphism may also result from metamorphic reactions and breakdown of other Zrbearing minerals (Fraser et al., 1997, 2004; Degeling et al., 2001; Möller et al., 2002, 2003; Tomkins et al., 2007). Fraser et al. (1997) and Möller et al. (2002) suggested that the source of newly precipitated zircon is $\mathrm{Zr}$ bearing rock-forming phases (e.g., garnet), which experience breakdown and release $\mathrm{Zr}$. The released $\mathrm{Zr}$ is not compatible with the breakdown product (e.g., with cordierite) and thus has to form a separate $\mathrm{Zr}$ phase, which could be zircon (Degeling et al., 2001; Möller et al., 2003). Zircon precipitation from other phases may also be facilitated by fluid. For example, Fraser et al. (2004) documented zircon rims precipitated during cooling stage from the hydrous fluid phase, which originated locally as a result of chlorite breakdown. The reactions with zircon precipitation in metamorphic rocks may be more efficient in the zones available for fluid infiltration, like fractures and shear zones (Bingen et al., 2001).

c. Zircon exsolution has been observed in nature (e.g., Ewing et al., 2013; Pape et al., 2016) and has been demonstrated experimentally with $\mathrm{Zr}$-rich rutile (Tomkins et al., 2007). Resulting zircon appears as thin exsolution lamellae or as small individual euhedral grains within rutile. Similarly, the metapelites from the IvreaVerbano Zone (IVZ) reveal thin zircon needles in rutile and chains of fine zircon grains framing rutile (Ewing et al., 2013; Pape et al., 2016).

In this contribution, we investigate unusual zircon textures, such as coronae found in dehydrated metapelitic granulites of the IVZ. We start with a review of the process of zircon precipitation from various $\mathrm{Zr}$-bearing phases, followed by an overview of known examples of zircon coronae. After a short geological background of the unit, we describe the sampled outcrop as well as the sample itself macroscopically. Then a short exposition of applied methods and microscopic description of the studied sample are presented, followed by a detailed depiction of observed zircon microstructures and textures. For the sake of completion, we also include micro- probe data of the studied sample. In the discussion, we suggest mineral reactions that could result in the formation of observed zircon coronae textures and then discuss the implications of our findings.

\subsection{Zr-bearing phases potentially associated with zircon precipitation}

Zircon dissolution and growth during metamorphism are not independent processes but must be coupled with the breakdown-growth of other phases and/or with various mineral-fluid reactions in the host rock (e.g., Tomkins et al., 2007; Austrheim et al., 2008). Metamorphic precipitation of zircon could be a result of the breakdown of and/or exsolution from various Zr-bearing phases (Davidson and van Breemen, 1988) such as garnet, amphibole, (clino)pyroxene and ilmenite (e.g., Fraser et al., 1997; Degeling et al., 2001; Möller et al., 2003; Söderlund et al., 2004; Harley et al., 2007; Kelsey et al., 2008; Morisset and Scoates, 2008), hemo-ilmenite (Morisset et al., 2005), baddeleyite (Bingen et al., 2001; Söderlund et al., 2004), rutile (Harley et al., 2007; Tomkins et al., 2007; Morisset and Scoates, 2008; Kelsey and Powell, 2011; Ewing et al., 2013, 2014; Pape et al., 2016), epidote, titanite (Kohn et al., 2015), chlorite (Fraser et al., 2004), and biotite (Vavra et al., 1996). Zircon coronae have been reported around Martian baddeleyite as a result of shock metamorphism (Moser et al., 2013). In mafic metamorphic rocks, precipitation of zircon is commonly associated with the Fe-Ti oxides (Bingen et al., 2001; Ewing et al., 2013, 2014) due to similar chemical properties of $\mathrm{Zr}$ and $\mathrm{Ti}$.

Zirconium and titanium both belong to group 4 in the periodic table, have close chemical properties and are usually regarded as relatively immobile trace elements (e.g., Mohamed and Hassanen, 1996). In the group of incompatible cations, $\mathrm{Zr}$ and Ti belong to high field strength (HFS) elements, which are smaller and are highly charged compared with large ion lithophile (LIL) elements. The chemical similarities result in a positive correlation between $\mathrm{Zr}$ and $\mathrm{Ti}$ for most rock suites and in their ability to replace each other in oxides (e.g., Morisset et al., 2005). The fact that $\mathrm{Zr}$ oxides and $\mathrm{Ti}$ oxides are spatially related in many rocks confirms chemical similarities between $\mathrm{Zr}$ and $\mathrm{Ti}$.

Thus, rutile and ilmenite are the main minerals interpreted to influence the $\mathrm{Zr}$ mass balance in metabasites in the absence of other $\mathrm{Zr}$ phases (e.g., Ferry and Watson, 2007; Tomkins et al., 2007; Morisset and Scoates, 2008; Ewing et al., 2013). In the absence of zircon, rutile can be the main phase holding $\mathrm{Zr}$ and $\mathrm{Hf}$ in the absence of zircon (Ewing et al., 2014). Zirconium is a common component of rutile, in which its content can reach 10000 ppm (e.g., Ewing et al., 2013); thus, Zr distributions generally reflect the formation and decomposition of rutile. The temperature dependence of $\mathrm{Zr}$ solubility in rutile can have a fundamental impact on the zircon growth rate (Kohn et al., 2015) and controls zircon stability (Kelsey and Powell, 2011). The zirconium-in-rutile thermometer for the 
rutile-quartz-zircon system was calibrated by a number of authors (e.g., Watson et al., 2006; Ferry and Watson, 2007; Tomkins et al., 2007; Lucassen et al., 2010; Ewing et al., 2013), who have shown a large temperature- and pressuredependent solubility of $\mathrm{Zr}$ in rutile. Zircon growth is frequently associated with the oxide transition from $\mathrm{Zr}$-rich rutile to ilmenite during late-stage exhumation and cooling under a large variety of $P-T$ conditions (Ewing et al., 2013). Magmatic and metamorphic ilmenite can also contain significant amounts of $\mathrm{Zr}$ (Bingen et al., 2001; Morisset et al., 2005; Charlier et al., 2007), up to more than 500 ppm (e.g., Morisset and Scoates, 2008). Consistently, many authors describe zircon precipitation on ilmenite (e.g., Bingen et al., 2001; Austrheim et al., 2008; Morisset and Scoates, 2008) (see below).

\subsection{Occurrences of fine-grain zircon and zircon corona textures}

In igneous rocks zircon usually forms euhedral elongated single crystals that are shaped by a combination of prismatic and pyramidal faces, whereas metamorphic zircon is characterized by roundish or irregular shapes (Corfu et al., 2003). Rarely, zircon has unusual saccharoidal or needleshaped morphology or forms coronae (Corfu et al., 2003 and references therein). Mineral-fluid interactions, decomposition of Zr-bearing minerals, and exsolution from Zr-bearing accessory and rock-forming minerals can result in such unusual zircon textures (e.g., Corfu et al., 2003 and references therein; Dempster et al., 2004, 2008; Rasmussen, 2005), even at low metamorphic grades (e.g., Dempster et al., 2008).

In natural samples, there are several documented examples of zircon coronae textures from igneous and metaigneous rocks (e.g., Bingen et al., 2001; Söderlund et al., 2004; Austrheim et al., 2008), as well as from metapelites of the IVZ (Pape et al., 2016). Such textures are found in rocks of different metamorphic grades, ranging from prehnite-pumpellyite to eclogite facies (Austrheim et al., 2008). It has been suggested that coronae textures may evolve in magmatic rocks as a result of slow cooling (Morisset et al., 2005) and in metamorphic rocks due to mineral-fluid reactions or exsolution with fluid-aided diffusion along grain boundaries during progressive metamorphism (e.g., Bingen et al., 2001).

One of the first descriptions of zircon coronae in mafic metaigneous rocks was done by Söderlund et al. (2004). The authors attributed formation of secondary fine-grained zircon to the breakdown of baddeleyite in the presence of silica (saccharoidal zircon) and to consumption of minerals that have trace amounts of $\mathrm{Zr}$, such as ilmenite (coronitic zircon). Both of these textural types of secondary zircon precipitated under prograde heating. Bingen et al. (2001) reported hatshaped zircon grains and coronae around ilmenite in granulites and amphibolites. Charlier et al. (2007) and Austrheim et al. (2008) reported fine-grained zircon chains around, but at a distance from ilmenite and rutile grains in metagabbros.
These authors suggested that zircon chains had grown around primary $\mathrm{Fe}-\mathrm{Ti}$ oxides and, therefore, trace the former grain boundaries. Fine-grained zircon was reported to frame some rutile grains in the metapelitic septae from the IVZ (Ewing et al., 2013; Pape et al., 2016). Morisset and Scoates (2008) reported $1-100 \mu \mathrm{m}$ thick zircon coronae around ilmenite in mafic plutonic rocks. They consider it to be a result of $\mathrm{Zr}$ diffusion from ilmenite during slow cooling, aided by hydrothermal fluid.

In this study, we report the two textural types of zircon coronae, characterized by various thickness and aspect ratio, occurring within $\mathrm{Fe}-\mathrm{Ti}$ oxides in granulitic metapelites. We present evidence that these textures formed as a product of the breakdown of $\mathrm{Fe}-\mathrm{Ti}$ oxides, which helps to understand the initial mineral paragenesis of the host rock and reveals former reaction fronts.

\section{Geological background and sampled locality}

The IVZ in the Southern Alps (northern Italy) consists of a NE-SW trending, steeply dipping sequence of metasedimentary and metaigneous basic rocks, ultrabasic mantle tectonites and a large underplated mafic igneous complex (Fig. 1a) (e.g., Brodie and Rutter, 1987; Brodie et al., 1992; Rutter et al., 2007). The sequence predominantly consists of metasedimentary rocks in the SE and metabasic rocks and strongly depleted metapelites in the NW. Metamorphic grade increases progressively from amphibolite facies in the SE to granulite facies in the NW. The IVZ is generally accepted as a section through the lower continental crust that experienced regional metamorphism during the uppermost Paleozoic and was tectonically overturned and uplifted. The IVZ is delimited by the Insubric Line in the NW and the Pogallo Line in the SE (Brodie and Rutter, 1987; Barboza et al., 1999; Rutter et al., 2007; Quick et al., 2009).

The sampled outcrop near the village Cuzzago (Val d'Ossola) shows massive, non-foliated granulite-facies metasediments, known as stronalites. Stronalite is defined as granulite-facies metapelite, consisting of garnet, sillimanite and biotite with leucocratic patches and veins, composed of quartz, plagioclase and K-feldspar (Bea and Montero, 1999) or as granoblastic graphite-sillimanite-garnet gneiss, one of the components of the IVZ septa (Barboza et al., 1999). Local foliation and/or compositional layering of stronalites is moderately folded (e.g., Kovaleva et al., 2014, their Fig. 1C). Stronalites are broken by orthogonal sets of fractures and crosscut by a contrasting layer of darker gneiss $\left(45^{\circ} 59^{\prime} 46.46^{\prime \prime} \mathrm{N}, 8^{\circ} 21^{\prime} 38.65^{\prime \prime} \mathrm{E}\right.$, sampled rock; Fig. 1b), which is macroscopically massive to weakly foliated, broken by abundant faults normal to foliation. The foliation of the layer strikes NW $\left(310^{\circ}\right.$, angle $\left.77^{\circ}\right)$ and the lineation plunges to the $\mathrm{NE}\left(34^{\circ}\right.$ towards $\left.038^{\circ}\right)$. No obvious kinematic indicators were observed in the host stronalites or in the sampled dark gneiss. However, detailed structural in- 

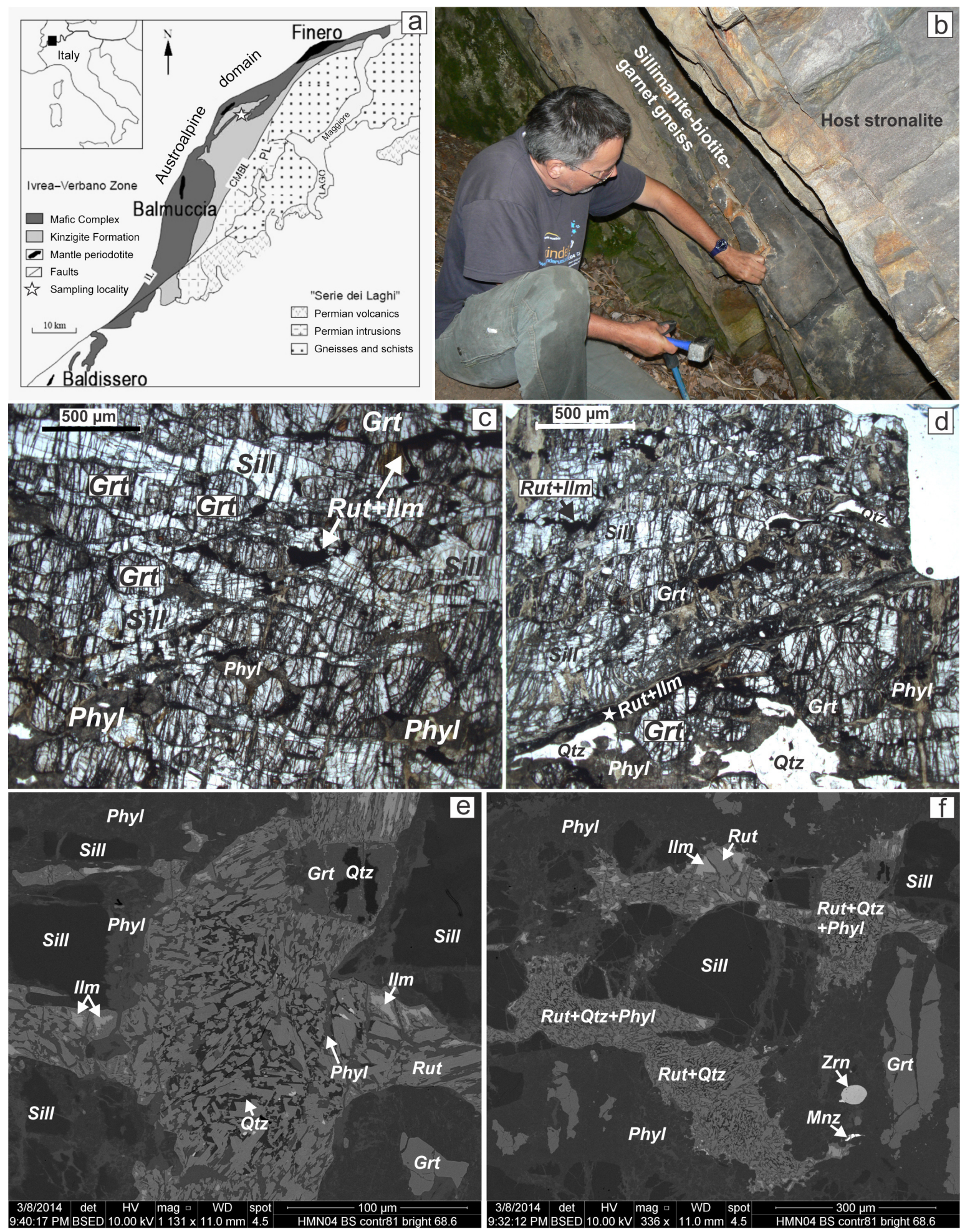

Figure 1. (a) Geological map of the Ivrea-Verbano Zone after Zanetti et al. (1999) with the sampling location indicated by a star. (b) Field photograph of the sampled outcrop with the dyke-shaped body of the sillimanite-biotite-garnet gneiss, interpreted as restitic, hosted by mylonitized and fractured stronalite. (c-d) Plain-polarized light photomicrographs. Two generations of veins are visible: black veins and pockets (Fe-Ti oxides) and brown-grey material (mixture of fine-grained phyllosilicates and K-feldspar). White star in panel (d) indicates the position of Fig. 4a. (e-f) BSE images with mineral paragenesis. Note in panel (e) that the rutile aggregate contains ilmenite cores (bright grey) and forms intergrowths with two different phases: phyllosilicates from the reaction rim (grey shade, slightly darker than rutile) and quartz (the darkest phase), all indicated by arrows. Sill: sillimanite, Grt: garnet, Qtz: quartz, Ilm: ilmenite, Rut: rutile, Rut + Qtz: rutile-quartz intergrowths, Phyl: fine-grained mixture of phyllosilicates, Zrn: zircon detrital grain, and Mnz: monazite. 
vestigations of the shear zones in the neighboring Val Strona revealed numerous structures that provide consistent evidence of sinistral shear (Siegesmund et al., 2008, and references therein).

The sampled gneiss consists of sillimanite-biotite-garnet intergrowths (Fig. 1c-d). Such restitic mineral assemblage in granulitic metapelites is interpreted to form due to partial melting and separation of leucosome (e.g., Barboza et al., 1999; Luvizotto and Zack, 2009; Ewing et al., 2013; Pape et al., 2016). Thus, the sampled gneiss is a restite, resulting from migmatization at peak granulite-facies conditions (e.g., Ewing et al., 2013). Partial melting is also responsible for apparent layering of host stronalites (Bea and Montero, 1999; Siegesmund et al., 2008), which are composed of alternating leucocratic and melanocratic layers.

The investigated sample came from the northwestern part of the IVZ, were metapelites and metagabbro were re-equilibrated under granulite-facies conditions prevailing during crustal attenuation-extension and contemporaneous magmatic underplating between 315 and $270 \mathrm{Ma}$ (Rutter et al., 2007; Quick et al., 2009; Sinigoi et al., 2011; Klötzli et al., 2014). $P-T$ estimates in the neighboring valleys, Val Strona and Val d'Ossola, indicated granulite-facies $P-T$ metamorphic conditions in the metapelites at a maximum of $750 \pm 50^{\circ} \mathrm{C}$ and $0.6 \pm 0.1 \mathrm{GPa}$ (Sills, 1984). Zrin-rutile temperatures of up to $850-930^{\circ} \mathrm{C}$ were obtained for granulite-facies metapelites from Val d'Ossola (Luvizotto and Zack, 2009).

Ubiquitous faulting of restitic material and both faulting and folding of host stronalite is due to intensive deformation taking place in granulitic metapelites during a long-time span after peak metamorphism (Siegesmund et al., 2008). According to Siegesmund et al. (2008) brittle and ductile deformation acted simultaneously during formation of shear zones, and their close interactions resulted in complex deformation microstructures.

\section{Sample preparation and analytical methods}

Zircon textures have been examined in situ using polished thin sections that were mechanically prepared with a final polish using $0.25 \mu \mathrm{m}$ diamond paste. Zircon grains were identified by backscattered-electron (BSE) imaging and were additionally characterized by cathodoluminescence (CL) imaging for the internal growth features using an FEI Inspect $\mathrm{S}$ scanning electron microscope equipped with a Gatan MonoCL system (Faculty of Earth Sciences, Geography and Astronomy, University of Vienna, Austria). Imaging conditions were at $10 \mathrm{kV}$ accelerating voltage, CL image resolution of $1500 \times 1500$ to $2500 \times 2500$ pixels using a dwell time of $80.0-150.0 \mathrm{~ms}$ and a probe current of $4.5-5.0 \mathrm{nA}$. Qualitative chemical compositions of host phases to zircon were made using an energy-dispersive X-ray (EDX) spectrometer. Orientation contrast images of zircon grains (e.g.,
Fig. 2) were taken using a forescatter electron (FSE) detector on a chemically polished sample surface. The FSE detector is mounted on the electron backscatter detector (EBSD) tube of a FEI Quanta 3D field emission gun (FEG) instrument (Faculty of Earth Sciences, Geography and Astronomy, University of Vienna, Austria), which is equipped with a Schottky field emission electron source. Electron beam conditions were $15 \mathrm{kV}$ accelerating voltage and 2.5-4 nA probe current using the analytic mode. Stage settings were at $70^{\circ}$ tilt and $14-16 \mathrm{~mm}$ working distance. Full quantitative chemical compositions of host minerals (Tables 1-2) were determined by Cameca SX 100 electron microprobe equipped with four wavelength-dispersive spectrometers (WDSs) and an EDX system for high quality of quantitative chemical analyses (Faculty of Earth Sciences, Geography and Astronomy, University of Vienna, Austria). Operating conditions were $15 \mathrm{kV}$ accelerating voltage and $100 \mathrm{nA}$ probe current. The detection limits in parts per million ( $\mathrm{ppm}$ ) for each microprobe analysis point are presented in Table S1 in the Supplement.

\section{Results}

\subsection{Microscopic description}

The generally restitic mineralogy of the sample is composed of garnet, biotite and sillimanite with minor amounts of cordierite, ilmenite, rutile, K-feldspar and quartz (Fig. 1cf). The primary mineralogy indicates prograde-peak mineral paragenesis, which consists of biotite, sillimanite and garnet. The foliation is formed by a fabric of elongated garnet and sillimanite crystals $0.5-1 \mathrm{~mm}$ in length that compose $80-90 \%$ of the sample (Fig. 1c-d). The stretching lineation is formed by elongated biotite crystals. Biotite contains numerous micrometer-sized apatite needles and is mostly replaced by chlorite. Primary metamorphic fabric is crosscut by several generations of veins and/or fractures (Fig. 2c-f), which were formed during cataclastic deformation and shear zone development (e.g., Siegesmund et al., 2008). Fractures are filled with post-peak and late hydration mineral assemblages. The earlier generation of veins is mostly composed of $\mathrm{Fe}-\mathrm{Ti}$ oxides and their intergrowths with quartz (Fig. 1c$\mathrm{d}$, black material). Fe-Ti oxides form aggregates with lobate boundaries with the primary minerals (garnet and sillimanite) (Fig. 1e-f). The network of veins of the later generation cross-cuts the veins of the earlier generation or follows their contacts. These later veins are more abundant than earlier ones and are composed of fine-grained phyllosilicates, such as chlorite, muscovite and/or phengite, and may also contain K-feldspar patches in the vein cores (Fig. 1c-d, greybrown material; Table 1). Abundance of phyllosilicates indicates post-metamorphic hydration reactions. Large (up to $2 \mathrm{~mm}$ in length and $0.3 \mathrm{~mm}$ thick) elongate quartz aggregates generally follow the vein distribution (Fig. 1d, bottom part). 
Table 1. Results of the microprobe analyses of the rock-forming silicates; n.d.: not detected. Grt: garnet, Bt: biotite, Chl: chlorite, Phyl: phyllosilicate(s), Pheng: phengite, and Mus: muscovite.

\begin{tabular}{|c|c|c|c|c|c|c|c|c|c|c|}
\hline Mineral & $\mathrm{SiO}_{2}$ & $\mathrm{TiO}_{2}$ & $\mathrm{Al}_{2} \mathrm{O}_{3}$ & $\mathrm{MgO}$ & $\mathrm{CaO}$ & $\mathrm{MnO}$ & $\mathrm{FeO}$ & $\mathrm{BaO}$ & $\mathrm{Na}_{2} \mathrm{O}$ & $\mathrm{K}_{2} \mathrm{O}$ \\
\hline Grt core & 38.90 & 0.02 & 22.22 & 9.33 & 1.51 & 0.31 & 28.60 & n.d. & n.d. & n.d. \\
\hline Grt core & 38.14 & 0.01 & 21.69 & 6.19 & 1.46 & 0.43 & 32.92 & n.d. & n.d. & n.d. \\
\hline Grt core & 38.16 & 0.01 & 21.70 & 6.37 & 1.46 & 0.49 & 32.51 & n.d. & 0.01 & n.d. \\
\hline Grt core & 39.01 & n.d. & 22.15 & 9.19 & 1.51 & 0.36 & 28.52 & n.d. & 0.02 & n.d. \\
\hline Grt core & 39.10 & 0.02 & 22.09 & 9.26 & 1.50 & 0.32 & 28.80 & n.d. & 0.02 & n.d. \\
\hline Grt core & 38.92 & 0.03 & 22.11 & 9.13 & 1.46 & 0.30 & 28.84 & n.d. & 0.03 & n.d. \\
\hline Grt core & 38.83 & 0.01 & 22.00 & 8.34 & 1.41 & 0.35 & 29.92 & n.d. & 0.03 & n.d. \\
\hline Grt core & 37.80 & 0.02 & 22.03 & 6.75 & 1.49 & 0.55 & 31.69 & n.d. & 0.01 & n.d. \\
\hline Grt rim & 38.81 & 0.01 & 22.12 & 8.58 & 1.54 & 0.34 & 29.44 & n.d. & 0.01 & n.d. \\
\hline Grt rim & 38.81 & 0.03 & 22.06 & 8.28 & 1.53 & 0.34 & 30.31 & n.d. & 0.03 & n.d. \\
\hline Grt rim & 38.95 & 0.01 & 21.82 & 7.73 & 1.52 & 0.40 & 30.77 & n.d. & n.d. & n.d. \\
\hline Grt rim & 38.35 & 0.01 & 21.95 & 7.77 & 1.51 & 0.42 & 30.35 & n.d. & 0.02 & n.d. \\
\hline Grt rim & 38.61 & 0.01 & 21.59 & 5.67 & 1.46 & 0.52 & 33.25 & n.d. & 0.01 & n.d. \\
\hline Grt rim & 38.39 & 0.07 & 21.78 & 5.96 & 1.46 & 0.53 & 32.82 & n.d. & n.d. & n.d. \\
\hline Grt rim & 37.93 & 0.21 & 21.49 & 5.65 & 1.52 & 0.55 & 32.93 & n.d. & 0.02 & n.d. \\
\hline Grt rim & 38.30 & 0.07 & 21.86 & 6.82 & 1.45 & 0.43 & 31.69 & n.d. & n.d. & n.d. \\
\hline Grt rim & 38.34 & 0.04 & 21.75 & 7.15 & 1.48 & 0.43 & 31.37 & n.d. & 0.01 & n.d. \\
\hline Grt rim & 37.35 & 0.01 & 21.12 & 3.85 & 1.50 & 0.87 & 35.51 & n.d. & n.d. & n.d. \\
\hline Grt rim & 37.38 & 0.03 & 21.12 & 3.86 & 1.45 & 0.81 & 35.22 & n.d. & n.d. & n.d. \\
\hline Grt rim & 37.65 & n.d. & 21.30 & 3.98 & 1.43 & 0.78 & 35.34 & n.d. & n.d. & n.d. \\
\hline Bt core & .15 & 6.27 & 1 & 15.79 & 0 & 3 & 10.75 & & 1 & 9.83 \\
\hline Bt core & 37.15 & 1.32 & 16.53 & 18.79 & 0.13 & 0.03 & 11.36 & n.d. & 0.10 & 9.16 \\
\hline $\mathrm{Bt}$ rim & 34.81 & 1.74 & 17.17 & 14.41 & 0.04 & n.d. & 17.50 & n.d. & 0.12 & 7.83 \\
\hline Bt rim & 35.22 & 2.82 & 16.59 & 13.55 & 0.02 & 0.04 & 18.27 & n.d. & 0.10 & 8.15 \\
\hline Bt rim & 35.61 & 1.46 & 16.14 & 14.38 & 0.16 & 0.02 & 17.94 & n.d. & 0.09 & 7.38 \\
\hline Bt rim & 34.75 & 1.27 & 17.16 & 13.37 & 0.03 & 0.04 & 19.60 & n.d. & 0.08 & 7.27 \\
\hline Chl over Bt & 29.75 & 0.03 & 18.37 & 16.40 & 0.10 & 0.05 & 22.91 & n.d. & n.d. & 0.14 \\
\hline Chl over Bt & 27.72 & 0.01 & 19.47 & 15.12 & 0.08 & 0.06 & 25.34 & n.d. & n.d. & 0.05 \\
\hline Chl over Bt & 27.29 & 0.21 & 19.76 & 15.84 & 0.03 & 0.07 & 24.21 & n.d. & n.d. & 0.03 \\
\hline Chl over Bt & 27.64 & 0.28 & 20.07 & 16.34 & 0.04 & 0.04 & 23.41 & 0.04 & n.d. & 0.04 \\
\hline Chl over Bt & 28.09 & 0.40 & 19.07 & 15.97 & 0.06 & 0.06 & 24.07 & 0.04 & n.d. & 0.20 \\
\hline Chl new & 27.14 & 0.02 & 21. & 14.10 & 0.03 & 0.09 & 24.90 & & n.d. & 0.07 \\
\hline Chl new & 24.84 & 0.03 & 22.94 & 12.98 & 0.05 & 0.06 & 26.44 & n.d. & n.d. & 0.06 \\
\hline Chl new & 28.47 & 0.02 & 18.16 & 15.53 & 0.06 & 0.05 & 24.92 & n.d. & 0.01 & 0.06 \\
\hline Chl new & 29.00 & 0.08 & 18.92 & 15.73 & 0.09 & 0.06 & 24.07 & n.d. & 0.02 & 0.21 \\
\hline Chl new & 29.44 & 0.06 & 19.27 & 15.65 & 0.07 & 0.06 & 24.44 & n.d. & 0.02 & 0.26 \\
\hline Chl new & 28.70 & 0.02 & 18.38 & 15.42 & 0.08 & 0.07 & 25.45 & 0.05 & 0.04 & 0.09 \\
\hline Chl new & 29.30 & 0.04 & 17.69 & 15.27 & 0.08 & 0.06 & 25.39 & 0.02 & 0.01 & 0.10 \\
\hline Chl new & 31.95 & 4.44 & 17.50 & 11.51 & 0.04 & 0.05 & 21.81 & 0.04 & 0.04 & 4.64 \\
\hline Phyl matrix & 44.34 & n.d. & 31.75 & 3.84 & 0.13 & n.d. & 6.06 & 0.28 & 0.33 & 7.70 \\
\hline Phyl matrix & 49.04 & 0.01 & 32.24 & 1.68 & 0.04 & n.d. & 1.63 & 0.17 & 0.18 & 10.58 \\
\hline Phyl matrix & 45.92 & 0.01 & 32.36 & 2.78 & 0.12 & n.d. & 4.12 & 0.47 & 0.32 & 8.63 \\
\hline Phyl matrix & 43.30 & 0.18 & 32.40 & 4.12 & 0.15 & 0.05 & 7.16 & n.d. & 0.33 & 7.12 \\
\hline Phyl matrix & 47.74 & 0.12 & 33.88 & 1.98 & 0.17 & 0.01 & 3.05 & n.d. & 0.42 & 8.67 \\
\hline Phyl matrix & 44.89 & 0.21 & 32.84 & 3.28 & 0.10 & n.d. & 4.87 & n.d. & 0.37 & 8.39 \\
\hline Phyl matrix & 44.91 & 0.02 & 32.38 & 3.38 & 0.17 & 0.02 & 5.17 & n.d. & 0.38 & 7.81 \\
\hline Phyl matrix & 38.78 & 0.05 & 28.79 & 6.94 & 0.10 & 0.02 & 12.02 & 0.19 & 0.27 & 4.91 \\
\hline Phyl matrix & 45.22 & 0.03 & 32.53 & 3.29 & 0.09 & 0.03 & 4.49 & 0.73 & 0.37 & 8.28 \\
\hline Pheng/Mus & 47.45 & 0.07 & 35.68 & 1.31 & 0.09 & n.d. & 1.65 & 0.32 & 0.40 & 9.53 \\
\hline Pheng/Mus & 48.41 & 0.17 & 35.13 & 1.34 & 0.14 & n.d. & 1.46 & 0.37 & 0.43 & 9.19 \\
\hline Pheng/Mus & 46.62 & 0.12 & 35.34 & 1.43 & 0.10 & 0.01 & 1.94 & 0.36 & 0.45 & 9.07 \\
\hline
\end{tabular}



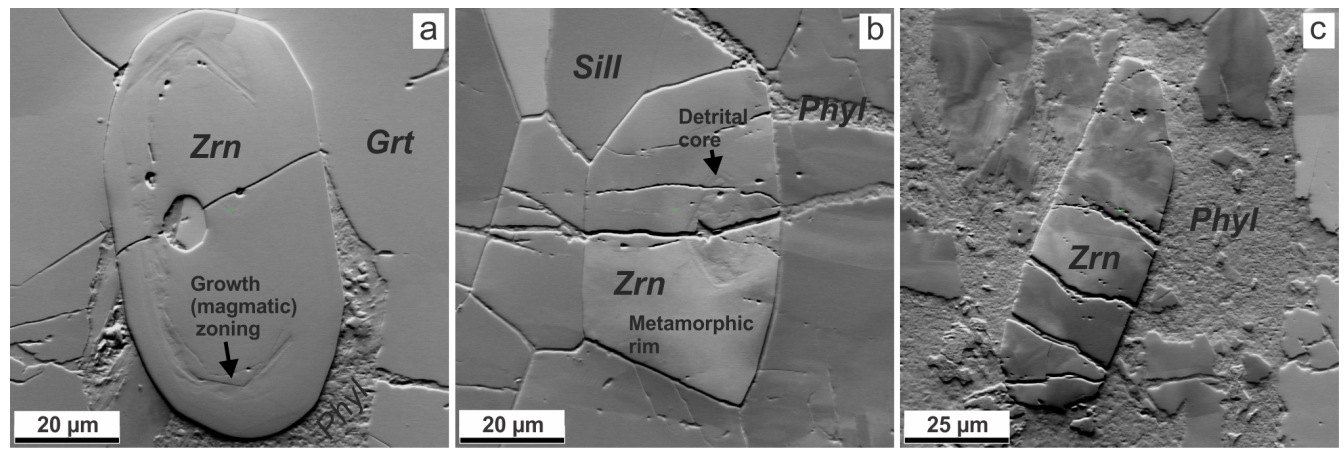

Figure 2. Orientation contrast images of detrital zircon in the sampled gneiss: (a) zircon grain hosted by garnet; note the concentric growth zoning. (b) Zircon grain hosted by sillimanite, note the small detrital core (right hand side) and wide metamorphic rim. (c) Zircon grain hosted by a fine-grained matrix that fills the veins; note intensive change in orientation contrast, especially conspicuous in the upper part of the grain. Orientation contrast image indicates the crystal-plastic deformation of the zircon grain and surrounding mineral fragments (garnet and sillimanite). Fracture surfaces appear to be dissolved. Mineral abbreviations as in Fig. 1.

Table 2. Results of the microprobe analyses of the Fe-Ti oxides, n.d.: not detected. Ilm: ilmenite and Rut: rutile.

\begin{tabular}{lrrrrrrrrrrr}
\hline Mineral & $\mathrm{Ta}_{2} \mathrm{O}_{5}$ & $\mathrm{SiO}_{2}$ & $\mathrm{TiO}_{2}$ & $\mathrm{Al}_{2} \mathrm{O}_{3}$ & $\mathrm{Cr}_{2} \mathrm{O}_{3}$ & $\mathrm{Nb}_{2} \mathrm{O}_{3}$ & $\mathrm{MgO}$ & $\mathrm{MnO}$ & $\mathrm{FeO}$ & $\mathrm{NiO}$ & $\mathrm{Total}$ \\
\hline $\mathrm{Ilm}$ & 0.04 & 0.03 & 52.82 & 0.02 & n.d. & 0.11 & 0.05 & 0.85 & 45.18 & n.d. & 99.15 \\
$\mathrm{Ilm}$ & 0.03 & 0.14 & 53.07 & 0.12 & 0.02 & 0.12 & 0.07 & 0.85 & 44.30 & 0.02 & 98.73 \\
$\mathrm{Ilm}$ & n.d. & 0.15 & 53.72 & 0.12 & n.d. & 0.04 & 0.03 & 0.89 & 43.56 & n.d. & 98.52 \\
\hline \multirow{2}{*}{ Rut } & n.d. & 0.60 & 98.31 & 0.22 & 0.08 & 0.25 & 0.04 & n.d. & 0.44 & n.d. & 99.92 \\
Rut & n.d. & 0.80 & 98.46 & 0.26 & 0.08 & 0.40 & 0.01 & n.d. & 0.40 & n.d. & 100.42 \\
Rut & n.d. & 2.10 & 93.19 & 1.42 & 0.06 & 0.22 & 0.60 & n.d. & 1.46 & n.d. & 99.03 \\
\hline
\end{tabular}

Veins and fractures form a conjugated orthogonal network, stretching in at least two directions in a 2-D section.

Accessory minerals are zircon and monazite (e.g., Figs. 1f, 2). Where hosted by garnet, zircon forms roundish elongated crystals with aspect ratios from $1: 1$ to $1: 3$ and lengths from 30 to $100 \mu \mathrm{m}$ (Fig. 2a). Where forming intergrowths with sillimanite, zircon reveals well-developed faces and forms triple junctions with the adjacent sillimanite grains (Fig. 2b), reflecting equilibration growth with sillimanite during prograde and peak metamorphism. Where hosted by finegrained material that fills fractures, zircon crystals are elongated, with an aspect ratio from $1: 2$ to $1: 3$; these grains are fractured and fragmented. The fragments have irregular dissolved boundaries and show evidence of crystalplastic deformation (Fig. 2c). Vermicular- and hat-shaped zircon aggregates and zircon coronae are spatially associated with each other and occur within ilmenite-rutile-quartz or rutile-quartz clusters and/or intergrowths (Figs. 3-5), which fill transgranular fractures and pockets in the gneiss (e.g., Fig. 4a).

\subsection{Zircon microstructures and textures}

Zircon textures reported in this study are coronae, by which we mean thin envelopes or shells in 3-D. Accordingly, in the 2-D plane of a sample they have thread- or worm-like shapes (depending on the thickness and aspect ratio). Zircon coronae in our sample occur as two main textural types. The first type is referred to as vermicular-shaped (coarser-grained) aggregates, which have a thickness $\geq 5 \mu \mathrm{m}$ and an aspect ratio of $1: 4$ to $1: 20$. The second type is referred to as coronae (finergrained) zircon aggregates, which have a thickness $\leq 1 \mu \mathrm{m}$ and an aspect ratio of approximately $1: 100$ (e.g., Figs. 3-4). There is also a third (subordinate) coronae type: hat-shaped aggregates that are the result of zircon coronae overgrowth preexisting (probably detrital) grains.

\subsubsection{Vermicular textures}

This textural type occurs as lamellae-like intergrowths with rutile. Some vermicular-shaped zircon grains are hosted by thin rutile-quartz intergrowths, in which rutile forms $<1 \mu \mathrm{m}$ thin and 1-3 $\mu \mathrm{m}$ long needles (Fig. $3 b$, matrix). Such needle shapes are evidence of rapid rutile recrystallization and reequilibration during the metamorphic evolution.

Figure $3 \mathrm{a}$ shows a zircon aggregate composed of three large vermicular-shaped grains (indicated by $\mathrm{V}$, enlarged in Fig. 3b, c, e). These vermicular grains are 5 to $15 \mu \mathrm{m}$ thick and 20 to $50 \mu \mathrm{m}$ long and have diffuse or auroral-light (Corfu et al., 2003) CL zoning (Fig. 3b, c, e). Vermicular-shaped grains have curved (Fig. 3b) or ragged (Fig. 3e) boundaries, a crescent-like shape (Fig. 3c, e) and are commonly broken 

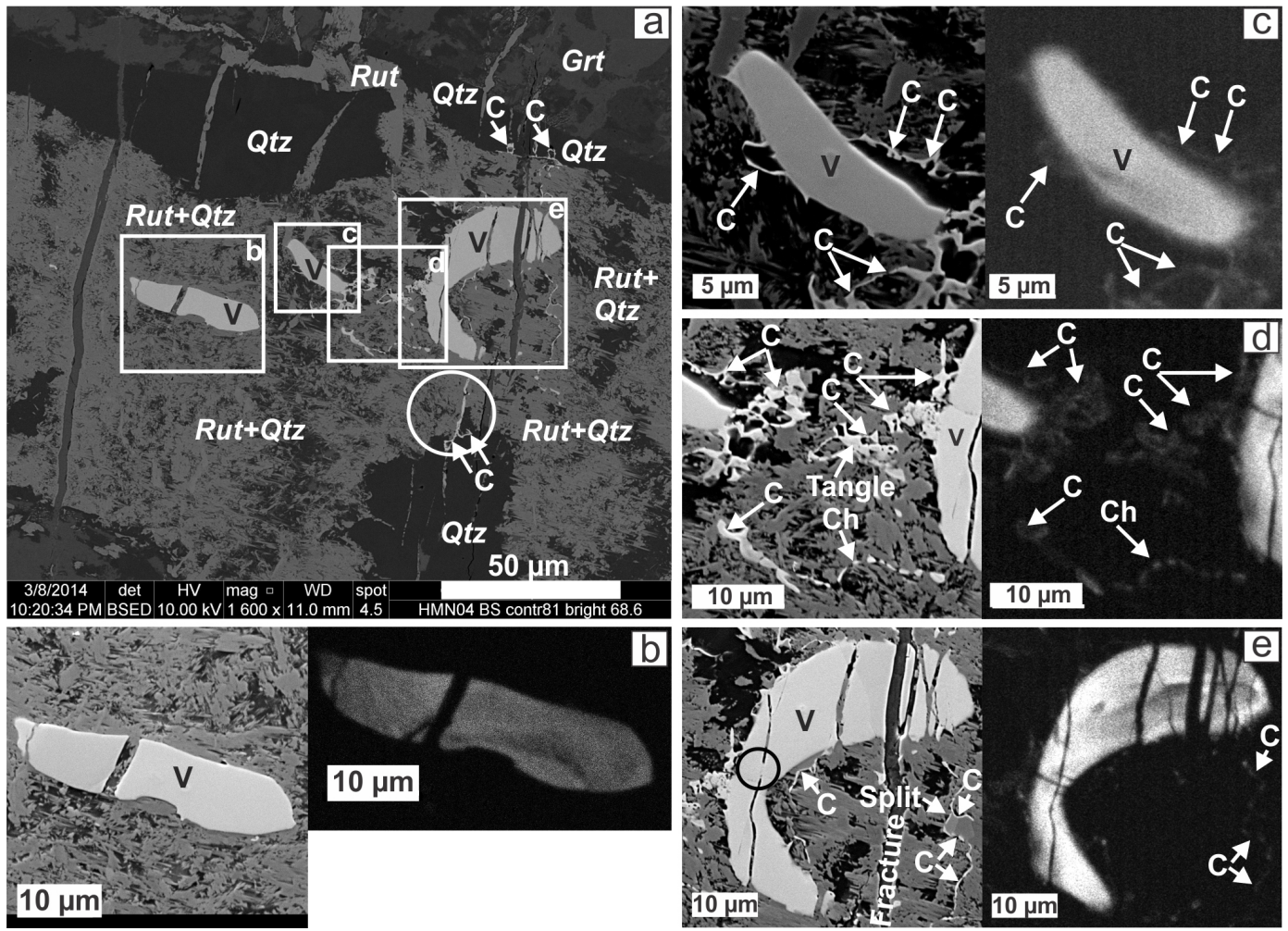

Figure 3. (a) BSE image of the vermicular-shaped zircon aggregates ("V") and zircon coronae ("C"). Arrows indicate zircon coronae that trace the quartz-rutile boundary or fill the cavities in quartz; the circle highlights a corona that fills the fracture. Mineral abbreviations as in Fig. 1. (c-e) Enlarged BSE (left) and CL (right) images of the areas indicated in panel (a). V highlights the vermicular-shaped zircon grains and $\mathrm{C}$ points to zircon coronae (the difference between $\mathrm{V}$ and $\mathrm{C}$ is in thickness). "Ch" in panel (d) points to the chain of submicron-sized zircon grains, and "Tangle" points to the tangled occurrence of coronae. Arrows in panel (e) indicate the directions of the reaction fronts, and "Split" points to the branching of zircon coronae. The circle in panel (e) highlights a partially healed fracture in vermicular zircon.

with transgranular fractures (Fig. 3b, e). Some of these fractures are traced in the host rock and filled with fine-grained phyllosilicates (Fig. 3e), which suggests that vermicular zircon predates the cataclasis and hydration with phyllosilicate growth. Furthermore, some fractures in vermicular grains (Fig. 3e) are partially healed by low-CL zircon material. This indicates that some precipitation of zircon has occurred after fracturing.

Another example of vermicular-shaped zircon aggregate is presented in Fig. 4. This texture is found in a vein of the early generation filled by the rutile-quartz intergrowths and elongate aggregates of quartz (Figs. 1d, 4a). A large zircon aggregate has a $\mathrm{W}$ shape and consists of two major fragments (Fig. 4b). The thickness of the vermicular zircon varies from 5 to $20 \mu \mathrm{m}$, and the total length is about $200 \mu \mathrm{m}$. The W-shaped vermicular aggregate shows diffuse CL zoning (Fig. 4d). The lower part of this aggregate used to extend to the right (Fig. 4c) and connect with the smaller vermicular grain at the right-hand side from the $\mathrm{W}$-shaped grain (Fig. 4a). This $50 \mu \mathrm{m}$ long extension was removed by subsequent polishing. The lower right tip of the aggregate drops below the surface plane of the thin section. The CL image and the EDX map of $\mathrm{Zr}$ distribution reveal the blurred trace around the lower right tip (Fig. 4d-e, grey arrows). This indicates that the zircon aggregate continues deeper into the sample at a shallow angle, and its signal is documented by CL and EDX from a few micrometers below the surface. As such, the aggregate represents an envelope in 3-D. The Wshaped zircon grain is plastically deformed in its central part, which is indicated by an orientation contrast image (Fig. 4f). Rotation of the lattice reaches $7^{\circ}$ with respect to the undeformed lattice (Kovaleva et al., 2016), indicating that this vermicular zircon grain predated shearing and ductile deformation.

Vermicular aggregates presented in Figs. 3 and 4 are associated with coronae textures, unlike aggregates in Fig. 5a. These aggregates are fractured and hosted by a rutilephyllosilicate aggregate, which fills the pocket between sillimanite and garnet (V in Fig. 5a).

\subsubsection{Coronae textures}

The matrix around some vermicular grains (Figs. 3c-e, 4c) contains abundant and continuous thin zircon coronae $(\mathrm{C}$ in Figs. 3a, c-e, 4a-e, 5) and fine-grained zircon chains (Ch in 

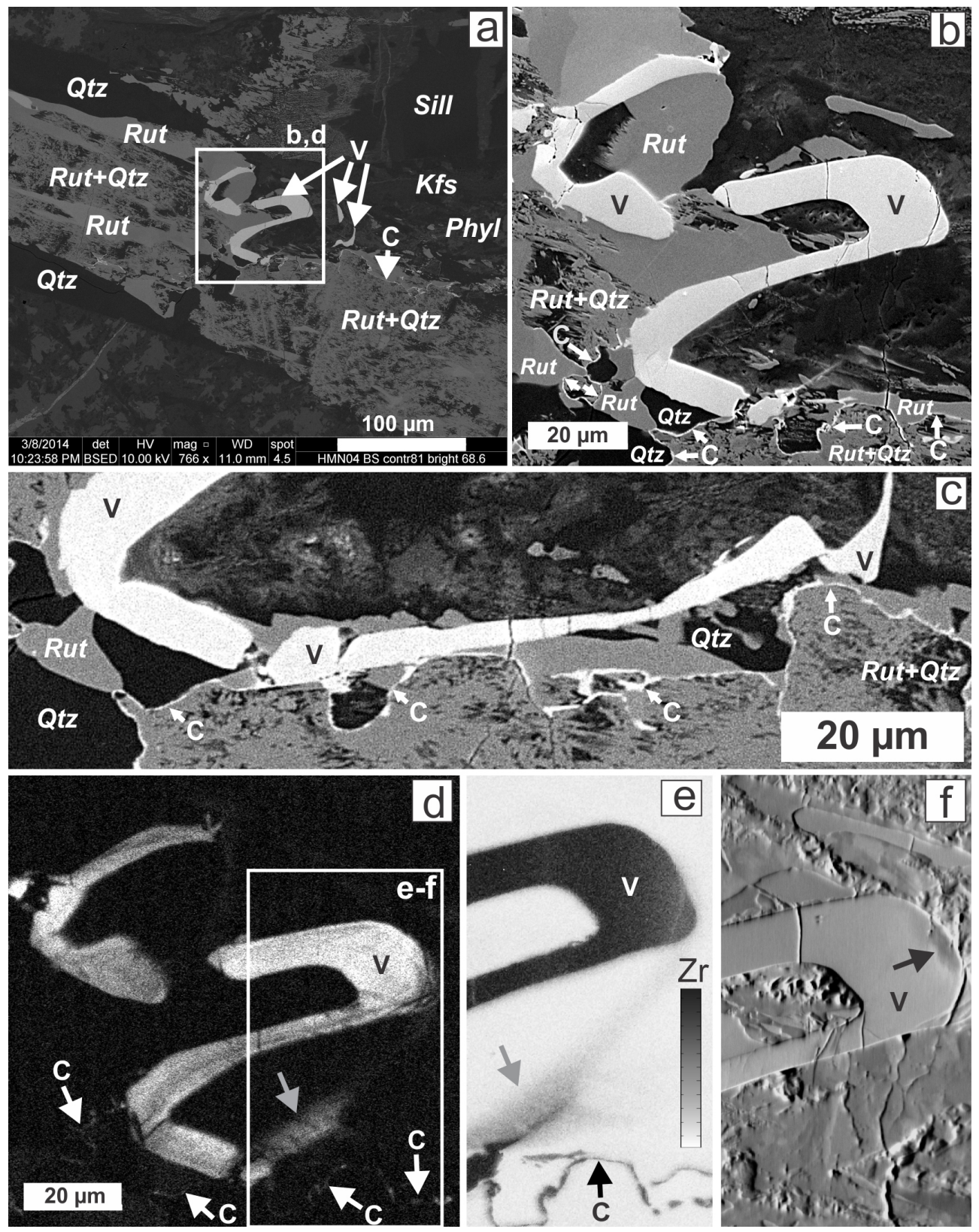

Figure 4. (a) BSE image of the zircon aggregate, which forms intergrowth with rutile and quartz. White rectangle highlights the area enlarged in panels (b) and (d). (b) Enlarged BSE image of the area indicated in panel (a). Arrows point out the direction of reaction fronts. (c) Enlarged area of the lower part of panel (b). The middle part of vermicular texture ("V") is present (it was subsequently polished away and thus absent in panels (a-b). Arrows point out the direction of the reaction front. (d) Enlarged CL image of the area indicated in panel (a). White arrows as in panel (b); grey arrow points to the wedged zircon texture that continues below the surface. (e) Qualitative EDX intensity map for Zr of the area indicated in panel (d). Black arrows point out the direction of reaction front; grey arrow as in panel (d). (f) Orientation contrast image of the area indicated in panel (d). Arrow points to plastically deformed tip of vermicular zircon grain. V in panels (a-f) highlights vermicular zircon grains and $\mathrm{C}$ highlights zircon coronae. Mineral abbreviations as in Fig. 1; Kfs: K-feldspar.

Figs. 3d, 4e). Coronae are $\leq 1 \mu \mathrm{m}$ thick and are up to $200 \mu \mathrm{m}$ long. They can be observed anywhere around and within rutile-quartz-phyllosilicates, ilmenite-rutile and ilmeniterutile-quartz aggregates (Figs. 3-5). Coronae are distributed rather randomly and are commonly found in the presence of larger zircon grains, which can be vermicular-shaped aggregates (e.g., Figs. 3-4), detrital grains (e.g., Fig. 5a, b, d) or peak metamorphic grains (e.g., Fig. 5c). At the same time, not all rutile-quartz intergrowths (Fig. 1e-f, 5a) and not all 

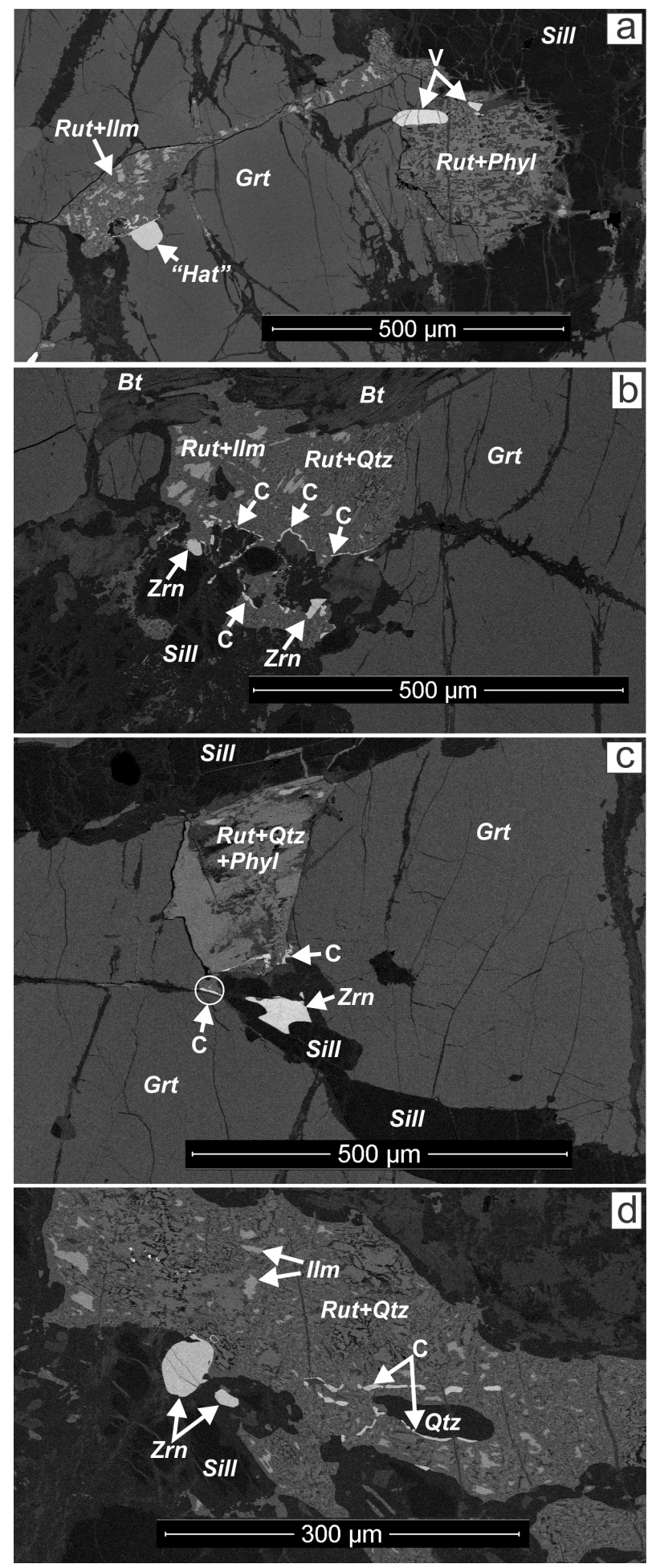

Figure 5. BSE images of mineral reactions that contain detrital zircon grains and associated zircon coronae. Mineral abbreviations are as in Fig. 1: Bt: biotite; Hat: hat-shaped zircon aggregate. "V" highlights the vermicular zircon grains, "C" points to the zircon coronae, and $\mathrm{Zrn}$ is the preexisting detrital and metamorphic zircon grains. Arrows in panel (b) show the direction of the mineral reaction front. vermicular-shaped grains (V in Fig. 5a) are associated with zircon coronae.

Both zircon coronae and fine-grained chains have distinguishable CL responses (Figs. 3c-e, 4d). Coronae occur as continuous threads that form splits (Figs. 3e, 4e) or isolated tangles (Fig. 3d). An especially dense network of zircon coronae is presented in Fig. 3d. Coronae are commonly attached to the larger vermicular zircon grains (Figs. 3c$\mathrm{e}, 4 \mathrm{~b}-\mathrm{c})$. Some coronae follow the phase boundaries between rutile-quartz aggregates and quartz (Figs. 3a, 4c, 5d) or rutile-quartz aggregates and sillimanite (C in Fig. 5b-c). Some thin zircon coronae extend outside of rutile-quartz intergrowths and fill fractures in quartz and garnet (Figs. 3a and $5 \mathrm{c}$ accordingly, circles), which suggests zircon coevalto post-fracturing precipitation.

\subsection{3 "Hat" textures}

The rutile-ilmenite intergrowths, adjacent to a rectangular zircon grain, fill a fracture in garnet adjacent to a rectangular zircon grain (Fig. 5a). Zircon coronae trace the boundary between garnet and rutile-ilmenite intergrowths and are connected to the rectangular zircon grain, so that the latter acquires a hat-like shape (Hat in Fig. 5a, after Bingen et al., 2001). Another example of similarly formed zircon aggregate does not have such a well-developed hat shape. It is a roundish zircon grain (Zrn in Fig. 5d), which is spatially associated with coronae and has short coronae outgrowths pointed towards the rutile-quartz aggregate.

\subsection{Microprobe data}

Mineral electron microprobe data are presented in Tables 1 and 2. These data are used to determine the temperature of metamorphism using the garnet-biotite thermometer and to support the suggestion of possible mineral-fluid reactions. The $X_{\mathrm{Fe}}$ of garnet is systematically lower in the cores than in the rims and in the smaller fragments. The same applies to the biotite (Table 1). Garnet rims are also systematically enriched in $\mathrm{Mn}$, compared to the cores. Compositions of $\mathrm{Fe}-$ Ti oxides (Table 2) demonstrate that rutile is much higher in $\mathrm{SiO}_{2}$ content than ilmenite. Rutile is also slightly enriched in such elements as $\mathrm{Al}, \mathrm{Cr}$ and $\mathrm{Nb}$, but lower in Mn (Table 2) compared to ilmenite.

\section{Discussion}

\subsection{Mineral reactions}

Mineral textures in the studied sample provide important information about the reactions that could have enhanced the growth of zircon coronae during metamorphism. We suggest the following reaction sequence: (1) formation of peak metamorphic phases and partial melting of the metapelites; (2) initial resorption of peak metamorphic phases and crys- 
tallization of interstitial ilmenite with lobate boundaries in fractures; (3) retrograde metamorphism, further resorption and fracturing of the high-temperature phases, hydration reactions with formation of phyllosilicates and decomposition of ilmenite to rutile; and (4) further cooling and recrystallization of rutile.

Temperature estimations were done using the garnetbiotite thermometer using microprobe data (Table 1). Various calibrations of this geothermometer (Thompson, 1976; Holdaway and Lee, 1977; Ferry and Spear, 1978; Hodges and Spear, 1982; Perchuk and Lavrent'eva, 1983; Bhattacharya et al., 1992) gave temperatures for garnet-biotite preserved cores of $570-700^{\circ} \mathrm{C}$, for inner rims $800-860^{\circ} \mathrm{C}$, and for outer rims $820-1090^{\circ} \mathrm{C}$. Estimations were done for pressures of 0.7 and $1.0 \mathrm{GPa}$. Pressure variations did not have any significant effect on the resulting temperatures. It is, however, possible, that garnet and biotite rims were affected by diffusion from the host environment during retrograde metamorphism. Mineral textures (Figs. 1e-f, 2c, 4a, 5) and microprobe analyses (Table 1) indicate that the initial granulitefacies garnet, biotite and sillimanite were intensely altered and resorbed. The fragments of garnet and sillimanite have ragged edges and are plastically deformed, dissolved and altered. $\mathrm{Mn}$ and $\mathrm{Fe}$, enriched in the rims of large garnet grains and in small garnet fragments, suggest garnet resorption and hydration during retrograde metamorphism (e.g., Tuccillo et al., 1990) after peak metamorphism. Thus, garnet rims do not indicate peak metamorphic temperatures; therefore, the rim temperatures are erroneous. More likely, peak metamorphic temperatures in this IVZ section were between 700 and $860^{\circ} \mathrm{C}$ (temperatures obtained for the cores and inner rims), in agreement with previous estimations (Sills, 1984; lowermost estimations of Luvizotto and Zack, 2009).

Pockets and fractures in garnet and sillimanite are filled with Fe-Ti oxide aggregates with lobate boundaries. Thus, ilmenite probably crystallized from the partial melt and/or fluid after the formation of peak metamorphic phases and after their resorption was initiated. Occasionally, veins with Fe-Ti oxides are associated with the quartz aggregates; thus, quartz possibly formed in the early generation of veins together with ilmenite. Ubiquitous fracturing of the rock (e.g., Fig. 1c-d) and crystal-plastic deformation of zircon (Figs. 2c, 4f) indicate the extreme conditions of post-peak metamorphism deformation (e.g., Siegesmund et al., 2008).

Further retrograde (greenschist facies) metamorphism led to hydration reactions and formation of veins filled with phyllosilicates and K-feldspar. The following features are regarded as evidence of intensive mineral-fluid reactions in the dry restitic granulite-facies rock (e.g., Rajesh et al., 2013): reaction rims around fragments of granulite-facies minerals (e.g., Fig. 1e), fine-grained phyllosilicate mixture that fills fractures (e.g., Fig. 1c-d, f), quartz veins (Figs. 1d, 4a), alteration of biotite with chloritization and exsolution of apatite needles. Water-rich fluids could have been sourced from the decomposing biotite (e.g., Pape et al., 2016). Rare il- menite cores are surrounded by rutile rims (Figs. 1e-f, 5ab, d). Thus, post-peak, trace-element-rich ilmenite was partially or entirely decomposed to rutile, which resulted in the migration of excess $\mathrm{Fe}$ into the matrix and into the garnet and biotite rims. Fe from ilmenite and $\mathrm{Mg}$ diffusing out of garnet and biotite rims are needed to compensate for the formation of the large volume of $\mathrm{Mg}-\mathrm{Fe}$ phyllosilicates in the second generation of veins (Figs. 1c-d, 2c; Table 1). K from biotite and $\mathrm{Al}$ from sillimanite would allow and/or favor the growth of K-feldspar in the veins (e.g., Fig. 4a). Excess $\mathrm{Hf}$ and $\mathrm{Zr}$ from breaking down ilmenite are responsible for the formation of zircon intergrowths with rutile (thick vermicular-shaped grains, e.g., Figs. 3b, c, e, 4a-c). Newly formed rutile is enriched in trace elements, possibly due to the decreased volume of Fe-Ti oxides (e.g., Austrheim et al., 2008). This rutile is also enriched in silica (Table 2) that requires sourcing $\mathrm{SiO}_{2}$ from the environment and may indicate solid solution of $\mathrm{SiO}_{2}$ in rutile (Taylor-Jones and Powell, 2015 ), which would play a role in a further reaction. Excess $\mathrm{Si}$, possibly derived from the fragmentation and dissolution of garnet and sillimanite, would form quartz veins and react with $\mathrm{Zr}$ to form zircon coronae. As for the apatite formation, $\mathrm{P}, \mathrm{F}, \mathrm{Cl}$ and $\mathrm{OH}$ could be derived either from decomposed biotite or were delivered by the water-rich fluid as components of a water brine from, for example, dissolution of monazite. However, the occurrence of apatite needles inside altered biotite grains points to genetic relationships between these two minerals.

Further cooling caused nonequilibrium recrystallization of rutile. Ewing et al. (2013) described partial replacement of rutile by other phases, characteristic for all granulitic metapelites from the IVZ. In our sample, we observe recrystallization of rutile with the formation of fine rutile-quartz intergrowths and thin zircon coronae around them. This took place during later stages of the rock evolution, when the temperature decreased and caused the $\mathrm{Zr}$ solubility in rutile to decrease. Therefore, we suggest the following stylized reaction (R1):

$\mathrm{Rut}_{\mathrm{Zr}-\mathrm{Hf}}+\mathrm{SiO}_{2}=\mathrm{Rut}_{2}+\mathrm{Qtz}+\mathrm{Zrn}_{\mathrm{cor}}$,

in which Rut $\mathrm{Zr-Hf}\left(=\mathrm{SiO}_{2-}, \mathrm{Zr}-\right.$ and Hf-bearing rutile) resulted from decomposition of ilmenite and $\mathrm{Rut}_{2}\left(=\mathrm{SiO}_{2-}\right.$, $\mathrm{Zr}$ - and Hf- depleted rutile) forms intergrowth with quartz (Qtz) and zircon coronae $\left(\mathrm{Zrn}_{\mathrm{cor}}\right)$. Quartz was exsolved from $\mathrm{SiO}_{2}$-rich rutile and formed thin intergrowths with the newly crystallized, trace-element-depleted rutile (e.g., Figs. 3, 4c). Zircon coronae produced in this way are very thin, suggesting slow reaction rates and a limited solubility of $\mathrm{Zr}$ in rutile at a low temperature (Tomkins et al., 2007; Ewing et al., 2013, 2014; Pape et al., 2016).

\subsection{Zircon textures}

Zircon grains hosted by garnet, sillimanite and fine-grained phyllosilicate matrix (Fig. 2a-c accordingly) represent detri- 
tal grains, enclosed within the main mineral phases during metamorphism. Zircon in garnet shows euhedral shapes and concentric growth zoning (Fig. 2a), indicating capture of detrital grains by metamorphic garnet. Zircon enclosed in sillimanite has detrital cores that are overgrown by metamorphic rims, which are in growth equilibrium with sillimanite (Figs. 2b, 5c). After the peak metamorphic conditions these detrital zircon grains seem to have been mostly inert and are therefore well-preserved. Zircon grains hosted by the finegrained phyllosilicate matrix in hydration veins are the most deformed and fractured and show dissolved and/or corroded surfaces (Fig. 2c). These latter grains were probably exposed to the post-peak metamorphic fluids. The dissolved material from their surfaces might have been transported with a fluid and serve as a source for the zircon coronae precipitation. We suggest, however, that this was not the main source of $\mathrm{Zr}$ for coronae zircon and that coronae mainly precipitated from $\mathrm{Fe}-\mathrm{Ti}$ oxides.

Vermicular-shaped aggregates of zircon (or thick coronae) and thin coronae (Figs. 3-5) have a different origin than the detrital grains (Fig. 2). It has been shown that zircon can grow from other $\mathrm{Zr}$-bearing phases as a result of mineral reactions and as a mineral response to the changing conditions (Bingen et al., 2001; Söderlund et al., 2004; Austrheim et al., 2008; Ewing et al., 2013, 2014; Kohn et al., 2015; Pape et al., 2016). Metamorphic (coronae) zircon in granulitefacies rocks may not be a product of peak metamorphism, but precipitate during the retrograde evolution (Tomkins et al., 2007). Zircon coronae textures are the evidence of zircon formation due to breakdown of $\mathrm{Zr}$-bearing $\mathrm{Fe}-\mathrm{Ti}$ oxides (e.g., Davidson and van Breemen, 1988; Fraser et al., 2004; Degeling et al., 2001). However, taking into account complexity of the textures and the fact that they were formed in more than one stage, we do not entirely exclude the possibility of exsolution of zircon from, for example, Zr-bearing rutile or exsolution from ilmenite before its breakdown (e.g., Bingen et al., 2001; Tomkins et al., 2007; Ewing et al., 2013; Pape et al., 2016). The possibility of the two-stage exsolution of $\mathrm{Zr}$ from $\mathrm{Fe}-\mathrm{Ti}$ oxides was suggested by Ewing et al., (2013). Our textural observations are consistent with this idea. The sketch in Fig. 6 shows stages (1) and (2) of zircon coronae formation:

1. After the peak metamorphic conditions, ilmenite was the main host phase for $\mathrm{Zr}$, together with the primary detrital zircon (Bingen et al., 2001). At the initial cooling stage it partially decomposed to rutile (Ewing et al., 2013). The expelled $\mathrm{Zr}$ was not entirely incorporated into the growing rutile and precipitated as new zircon (Fig. 6). Formation of zircon vermicular aggregates preceded brittle and ductile deformation of the rock. Vermicular grains in 3-D volume represent curved envelope-type aggregates (Fig. 4b-e), thus resembling coronae in shape (e.g., Bingen et al., 2001). However, they are thicker than what was previously observed for zircon. Therefore, we interpret vermicular grains as evolved coronae. The thickness of these coronae should be controlled by reaction and cooling rates (Kohn et al., 2015). At comparatively high temperatures and slow reaction rates, zircon coronae grew thick, and formed lamellae-like intergrowths with the newly forming rutile (e.g., Fig. 4a-b). Formation of similar exsolution lamellae was described for many metamorphic minerals (e.g., Zhang and Liou, 2000).

2. In contrast with the thick coronae, formation of thin zircon coronae during Reaction (R1) occurred at lower temperatures, simultaneous with or soon after fracturing, as some of these coronae fill fractures (Figs. 3a, e, 5c). Fracture filling also indicates local $\mathrm{Zr}$ mobility, aided by fluid. At lower temperatures rutile recrystallizes and progressively incorporates less $\mathrm{Zr}$ (Ewing et al., 2013) than the high-temperature rutile, according to $\mathrm{Zr}$-in-rutile thermometer models (Watson et al., 2006; Ferry and Watson, 2007). Thus, the excess $\mathrm{Zr}$ in the cooling system should be hosted by other Zr-bearing phases, most commonly by zircon (e.g., Pape et al., 2016). Crystallization of thin $(\leq 1 \mu \mathrm{m})$ zircon coronae and thin needle-shaped $1-3 \mu \mathrm{m}$ long rutile grains indicates rapid cooling resulting in non-equilibrium recrystallization of $\mathrm{Zr}$-bearing rutile, when $\mathrm{Zr}$ and $\mathrm{Hf}$ were expelled from the host grain (Ewing et al., 2013). This occurred after the initial cooling during the exhumation stage (Ewing et al., 2014; Kohn et al., 2015). The rutile grains that did not recrystallize usually occur in intimate contact with the rutile-quartz intergrowths and are separated from them by zircon coronae (e.g., Fig. 4c). Thus, it is possible to indicate the direction of the recrystallization front. Earlier zircon grains serve as the nucleation spots for thin zircon coronae, which is similar to the low-temperature textures described by Rasmussen (2005).

Zircon coronae in our sample are different from those described in Bingen et al. (2001), Charlier et al. (2007), and Morisset and Scoates (2008), who only observed coronae at the boundary of the (former) ilmenite grains. The described textures are also different from the coronae reported by Austrheim et al. (2008) and Pape et al. (2016), in which zircon forms continuous chains or closed contours of small grains. However, zircon coronae in all cases (described in earlier literature and here) represent 3-D shells and/or envelopes around the reacting grains (Bingen et al., 2001). Textures, indicating reaction fronts of rutile recrystallization, have not been found by Pape et al. (2016), even though these authors searched these features. In contrast, in our sample we observe former reaction fronts formed by tangled and split zircon coronae within recrystallized rutile aggregates. Split coronae may show different reaction fronts converging to one point (Figs. 3e, 4e). The reaction fronts moved from rutile-quartz intergrowths towards unreacted rutile, forming rutile-quartz 


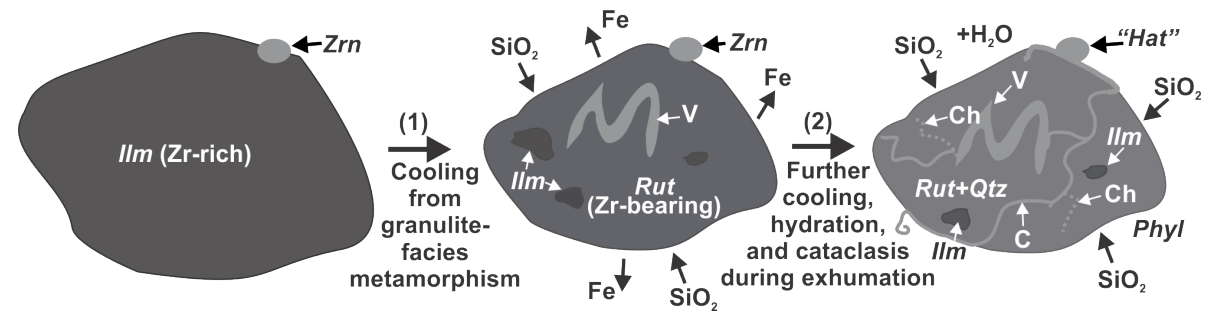

Figure 6. Sketch of the formation stages of zircon coronae. Post-peak metamorphic Zr-rich ilmenite fills the pocket between peak metamorphic minerals and has lobate boundaries. During the initial retrograde cooling (1) it decomposes to $\mathrm{Zr}$ - and $\mathrm{SiO}_{2}$-bearing rutile and vermicular-shaped zircon aggregates. The system loses $\mathrm{Fe}$ and requires $\mathrm{SiO}_{2}$ from the surrounding phases; the volume of $\mathrm{Fe}-\mathrm{Ti}$ oxide decreases. Further cooling, hydration and cataclasis during exhumation (2) results in recrystallization of Zr-bearing rutile to rutile-quartz intergrowths with precipitation of thin zircon coronae. At this point the reaction requires $\mathrm{SiO}_{2}$ and aqueous fluid from the surroundings. Abbreviations as in Figs. 1, 3 and 5.

embayments in the latter, rimmed by zircon coronae (e.g., Fig. 4c, arrows show the directions of the reaction front). The chains of small zircon grains are effectively the same as zircon coronae and are similar to those described in Austrheim et al. (2008). The hat-shaped zircon grains are formed by coronae that are connected to the larger zircon grains (Fig. 5a) and thus represent aggregates formed by different zircon generations.

Not all rutile aggregates in our sample are associated with zircon coronae. Similarly, the diversity in appearance of rutile grains from the same sample was described by Pape et al. (2016) for IVZ metapelites. This can be due to (a) thin section cut that does not reveal associated coronae or (b) only local recrystallization of rutile (e.g., due to locally elevated strain or inhomogeneous distribution of fluid), so that the rest of the rutile still contains a significant amount of $\mathrm{Zr}$. In the case of (b), Zr-in-rutile thermobarometry can be applied to the $\mathrm{Zr}$-enriched rutile to estimate the temperature of ilmenite decomposition and coeval formation of vermicular zircon (e.g., Ewing et al., 2013).

\section{Conclusions and implications}

In our study, we demonstrate that zircon coronae can form within and around $\mathrm{Fe}-\mathrm{Ti}$ oxides in metapelites during cooling and hydration after peak granulite-facies metamorphism. Zircon formed as a result of breakdown (exsolution) of ilmenite and rutile. Formation of zircon coronae occurred in two distinct stages and resulted in (1) thick $(5-20 \mu \mathrm{m})$ vermicular-shaped grains presumably formed during breakdown of Zr-bearing ilmenite to Zr-bearing rutile, and in (2) thin $(\leq 1 \mu \mathrm{m})$ corona aggregates and submicron-grain chains formed due to low-temperature recrystallization of $\mathrm{Zr}$ bearing rutile (Fig. 6). Two zircon-forming episodes were separated in time and represent two evolution stages of the sampled rock and could therefore be connected with the evolution of the Ivrea-Verbano Zone on a larger scale.
We report a new textural relationship between zircon and host rutile grains, as only exsolution needles of zircon in rutile and small zircon grains framing rutile were described in metapelites before (e.g., Ewing et al., 2013; Pape et al., 2016). We describe zircon coronae in metasedimentary rocks, in contrast with the previous authors, who reported similar textures in metaigneous rocks (e.g., Bingen et al., 2001; Austrheim et al., 2008 and references therein).

The detailed study of zircon corona textures can have a significant influence on the trace element balance calculations for the bulk rock, provides a tool for the reconstruction of metamorphic mineral-fluid reactions and helps derive the direction of rutile recrystallization reaction fronts. Moreover, precipitated zircon can potentially be used in geochronology for in situ dating of metamorphic evolution stages and may yield the isotopic age of metamorphic reactions (e.g., Charlier et al., 2007; Ewing et al., 2013). The trace elements in zircon can be measured to fingerprint different fluid infiltrationrecrystallization events. They can be used in thermobarometry for estimating the $P-T$ conditions of the ilmenite breakdown and formation of $\mathrm{Zr}$-bearing rutile and the $P-T$ conditions of the $\mathrm{Zr}$ exsolution from rutile. For the latter, $\mathrm{Zr}$ in-rutile, Ti-in-zircon and Si-in-rutile thermometers can be applied (e.g., Ewing et al., 2013; Pape et al., 2016).

Data availability. There are no datasets associated with the manuscript other than those included in the paper and the Supplement.

\section{The Supplement related to this article is available online at https://doi.org/10.5194/se-8-789-2017-supplement.}

Author contributions. EK and UK were responsible for sampling. EK performed laboratory work, SEM and EMPA analysis, data reduction and analysis, and drafted the paper. HA and UK conceptu- 
alized the study, oversaw the progression of the work and advised on interpretation.

Competing interests. The authors declare that they have no conflict of interest.

Acknowledgements. This study was funded by the University of Vienna (doctoral school "DOGMA", project IK 052). The authors acknowledge access to the laboratory for scanning electron microscopy and focused ion beam applications, Faculty of Earth Sciences, Geography and Astronomy at the University of Vienna (Austria), and specifically Gerlinde Habler, who acquired the orientation contrast images presented in this study. The authors are grateful to Rainer Abart, Claudia Beybel, Franz Biedermann, Sigrid Hrabe, Hugh Rice and all colleagues of the FOR741 research group for fruitful discussions; to the Geologische Bundesanstalt (GBA) of Austria and Christian Auer for access to the SEM; to the Department of Geology at the University of the Free State for the support in writing this paper. Comments of Nigel Kelly, Fernando Corfu and Roberto Weinberg helped to improve the text greatly.

Edited by: Roberto Weinberg

Reviewed by: Fernando Corfu and Nigel Kelly

\section{References}

Austrheim, H., Putnis, C. V., Engvik, A. K., and Putnis, A.: Zircon coronae around Fe-Ti oxides: a physical reference frame for metamorphic and metasomatic reactions, Contrib. Mineral. Petr., 156, 517-527, 2008.

Barboza, S. A., Bergantz, G. W., and Brown, M.: Regional granulite facies metamorphism in the Ivrea zone: is the Mafic Complex the smoking gun or a red herring?, Geology, 27, 447-450, 1999.

Bea, F. and Montero, P.: Behavior of accessory phases and redistribution of $\mathrm{Zr}$, REE, Y, Th, and $\mathrm{U}$ during metamorphism and partial melting of metapelites in the lower crust: An example from the Kinzigite Formation of Ivrea-Verbano, NW Italy, Geochim. Cosmochim. Acta, 63, 1133-1153, 1999.

Bhattacharya, A., Mohanty, L., Maji, A., Sen, S. K., and Raith, M.: Non-ideal mixing in the phlogopite-annite binary: constraints from experimental data on $\mathrm{Mg}$-Fe partitioning and a reformulation of the biotite-garnet geothermometer, Contrib. Mineral. Petrol., 111, 87-93, 1992.

Bingen, B., Austrheim, H., and Whitehouse, M.: Ilmenite as a source for zirconium during high-grade metamorphism? Textural evidence from the Caledonides of western Norway and implications for zircon geochronology, J. Petrol., 42, 355-375, 2001.

Brodie, K. H. and Rutter, E. H.: Deep crustal extensional faulting in the Ivrea zone of northern Italy, Tectonophysics, 140, 193-212, 1987.

Brodie, K. H., Rutter, E. H., and Evans, P.: On the structure of the Ivrea-Verbano Zone (northern Italy) and its implications for present-day lower continental crust geometry, Terra Nova, 4, 34$39,1992$.
Charlier, B., Skår, Ø., Korneliussen, A., Duchesne, J.-C., and Auwera, J. V.: Ilmenite composition in the Tellnes Fe-Ti deposit, SW Norway: fractional crystallization, postcumulus evolution and ilmenite-zircon relation, Contrib. Mineral. Petr., 154, 119-134, 2007.

Corfu, F., Hanchar, J. M., Hoskin, P. W. O., and Kinny, P.: Atlas of zircon textures, in: Zircon, Reviews in Mineralogy and Geochemistry, 53, edited by: Hanchar, J. M. and Hoskin, P. W. O., Mineralogical Society of America, Washington, DC, USA, 468500, 2003.

Davidson, A. and van Breemen, O.: Baddeleyite-zircon relationships in coronitic metagabbro, Grenville Province, Ontario: implications for geochronology, Contrib. Mineral. Petr., 100, 291299, 1988.

Degeling, H., Eggins, S., and Ellis, D. J.: Zr budgets for metamorphic reactions, and the formation of zircon from garnet breakdown, Min. Mag., 65, 749-758, 2001.

Dempster, T. J., Hay, D. C., and Bluck, B. J.: Zircon growth in slate, Geology, 32, 221-224, 2004.

Dempster, T. J., Hay, D. C., Gordon, S. H., and Kelly, N. M.: Microzircon: origin and evolution during metamorphism, J. Metamorph. Geol., 26, 499-507, 2008.

Ewing, T. A., Hermann, J., and Rubatto, D.: The robustness of the Zr-in-rutile and Ti-in-zircon thermometers during high-temperature metamorphism (Ivrea-Verbano Zone, northern Italy), Contrib. Mineral. Petr., 165, 757-779, 2013.

Ewing, T. A., Rubatto, D., and Hermann, J.: Hafnium isotopes and $\mathrm{Zr} / \mathrm{Hf}$ of rutile and zircon from lower crustal metapelites (IvreaVerbano Zone, Italy): Implications for chemical differentiation of the crust, Earth. Planet. Sc. Lett., 389, 106-118, 2014.

Ferry, J. M. and Spear, F. S.: Experimental calibration of the partitioning of $\mathrm{Fe}$ and $\mathrm{Mg}$ between biotite and garnet, Contrib. Mineral. Petrol., 66, 113-117, 1978.

Ferry, J. M. and Watson, E. B.: New thermodynamic models and revised calibrations for the Ti-in-zircon and $\mathrm{Zr}$-in-rutile thermometers, Contrib. Mineral. Petr., 154, 429-437, 2007.

Fraser, G., Ellis, D., and Eggins, S.: Zirconium abundance in granulite-facies minerals, with implications for zircon geochronology in high-grade rocks, Geology, 25, 607-610, 1997.

Fraser, G. L., Pattison, D. R. M., and Heaman, L. M.: Age of the Ballachulish and Glencoe Igneous Complexes (Scottish Highlands), and paragenesis of zircon, monazite and baddeleyite in the Ballachulish Aureole, J. Geol. Soc. London, 161, 447-462, 2004.

Harley, S. L., Kelly, N. M., and Möller, A.: Zircon behaviour and the thermal histories of mountain chains, Elements, 3, 25-30, 2007.

Harrison, M. T. and Watson, E. B.: Kinetics of zircon dissolution and zirconium diffusion in granitic melts of variable water content, Contrib. Mineral. Petr., 84, 66-72, 1983.

Hay, D. C. and Dempster, T. J.: Zircon behavior during lowtemperature metamorphism, J. Petrol., 50, 571-589, 2009.

Hay, D. C., Dempster, T. J., Lee, M. R., and Brown, D. J.: Anatomy of a low temperature zircon outgrowth, Contrib. Mineral. Petr., 159, 81-92, 2010.

Hodges, K. V. and Spear, F. S.: Geothermometry, geobarometry and the $\mathrm{Al}_{2} \mathrm{SiO}_{5}$ triple point at Mt. Moosilauke, New Hampshire, Am. Mineral., 67, 1118-1134, 1982. 
Holdaway, M. J. and Lee, S. M.: Fe-Mg cordierite stability in high grade pelitic rocks based on experimental, theoretical and natural observations, Contrib. Mineral. Petr., 63, 175-198, 1977.

Kelsey, D. E. and Powell, R.: Progress in linking accessory mineral growth and breakdown to major mineral evolution in metamorphic rocks: a thermodynamic approach in the $\mathrm{Na}_{2} \mathrm{O}-\mathrm{CaO}-$ $\mathrm{K}_{2} \mathrm{O}-\mathrm{FeO}-\mathrm{MgO}-\mathrm{Al}_{2} \mathrm{O}_{3}-\mathrm{SiO}_{2}-\mathrm{H}_{2} \mathrm{O}-\mathrm{TiO}_{2}-\mathrm{ZrO}_{2}$ system, J. Metamorph. Geol., 29, 151-166, 2011.

Kelsey, D. E., Clark, C., and Hand, M.: Thermobarometric modelling of zircon and monazite growth in melt-bearing systems: examples using model metapelitic and metapsammitic granulites, J. Metamorph. Geol., 26, 199-212, 2008.

Klötzli, U. S., Sinigoi, S., Quick, J. E., Demarchi, G., Tassinari, C. C. G., Sato, K., and Günes, Z.: Duration of igneous activity in the Sesia Magmatic System and implications for high-temperature metamorphism in the Ivrea-Verbano deep crust, Lithos, 206207, 19-33, 2014.

Kohn, M. J., Corrie, S. L., and Markley, C.: The fall and rise of metamorphic zircon, Am. Mineral., 100, 897-908, 2015.

Kovaleva, E., Klötzli, U., Habler, G., and Libowitzky, E.: Finite lattice distortion patterns in plastically deformed zircon grains, Solid Earth, 5, 1099-1122, https://doi.org/10.5194/se-5-10992014, 2014.

Kovaleva, E., Klötzli, U., and Habler. G.: On the geometric relationship between deformation microstructures in zircon and the kinematic framework of the shear zone, Lithos, 262, 192-212, 2016.

Lucassen, F., Dulski, P., Abart, R., Franz, G., Rhede, D., and Romer, R. L.: Redistribution of HFSE elements during rutile replacement by titanite, Contrib. Mineral. Petr., 160, 279-295, 2010.

Luvizotto, G. L. and Zack, T.: Nb and Zr behavior in rutile during high-grade metamorphism and retrogression: an example from the Ivrea-Verbano Zone, Chem. Geol., 261, 303-317, 2009.

Mohamed, F. H. and Hassanen, M. A.: Geochemical evolution of arc-related mafic plutonism in the Umm Naggat district, Eastern Desert of Egypt, J. Afr. Earth. Sci., 22. 269-283, 1996.

Möller, A., O’Brien, P. J., Kennedy, A., and Kröner, A.: Polyphase zircon in ultrahigh-temperature granulites (Rogaland, SW Norway): constraints for $\mathrm{Pb}$ diffusion in zircon, J. Metamorph. Geol., 20, 727-740, 2002.

Möller, A., O’Brien, P. J., Kennedy, A., and Kröner, A.: Linking growth episodes of zircon and metamorphic textures to zircon chemistry: an example from the ultrahigh-temperature granulites of Rogaland (SW Norway), in: Geochronology: Linking the isotopic record with petrology and textures, edited by: Vance, D., Müller, W., and Villa, I. M., J. Geol. Soc. London Sp. Publ., 220, 65-81, London, UK, 2003.

Morisset, C. E. and Scoates, J. S.: Origin of zircon rims around ilmenite in mafic plutonic rocks of proterozoic anorthosite suites, Can. Mineral., 46, 289-304, 2008.

Morisset, C. E., Scoates, J. S., and Weis, D.: Exsolution origin for zircon rims around hemo-ilmenite in magmatic $\mathrm{Fe}-\mathrm{Ti}$ oxide deposits, Geohimica et Cosmochimica Acta, 15th Annual V. M. Goldschmidt Conference, 21-25 May 2005, Moscow, Idaho, USA, A16, 2005.

Moser, D. E., Chamberlain, K. R., Tait, K. T., Schmitt, A. K., Darling, J. R., Barker, I. R., and Hyde, B. C.: Solving the Martian meteorite age conundrum using micro-baddeleyite and launchgenerated zircon, Nature, 499, 454-458, 2013.
Pape, J., Mezger, K., and Robyr, M.: A systematic evaluation of the Zr-in-rutile thermometer in ultra-high temperature (UHT) rocks, Contrib. Mineral. Petr., 171, 44, https://doi.org/10.1007/s00410016-1254-8, 2016.

Perchuk, L. L. and Lavrent'eva, I. V.: Experimental investigation of exchange equilibria in the system cordierite-garnet-biotite, in: Kinetics and equilibrium in mineral reactions, edited by: Saxena, S. K., Springer, New York, USA, 199-239, 1983.

Quick, J. E., Sinigoi, S., Peressini, G., Demarchi, G., Wooden, J. L., and Sbisà, A.: Magmatic plumbing of a large Permian caldera exposed to a depth of $25 \mathrm{~km}$, Geology, 37, 603-606, 2009.

Rajesh, H. M., Belyanin, G. A., Safonov, O. G., Kovaleva, E. I., Golunova, M. A., and Van Reenen, D. D.: Fluid-induced dehydration of the paleoarchean Sand River biotite-hornblende gneiss, Central Zone, Limpopo Complex, South Africa, J. Petrol., 54, 41-74, 2013.

Rasmussen, B.: Zircon growth in very low grade metasedimentary rocks: evidence for zirconium mobility at $\sim 250{ }^{\circ} \mathrm{C}$, Contrib. Mineral. Petr., 150, 146-155, 2005.

Rubatto, D., Müntener, O., Barnhoorn, A., and Gregory, C.: Dissolution-reprecipitation of zircon at low-temperature, highpressure conditions (Lanzo Massif, Italy), Am. Mineral., 93, 1519-1529, 2008.

Rutter, E. H., Brodie, K. H., James, T., and Burlini, L.: Large-scale folding in the upper part of the Ivrea-Verbano zone, NW Italy, J. Struct. Geol., 29, 1-17, 2007.

Siegesmund, S., Layer, P., Dunkl, I., Vollbrecht, A., Steenken, A., Wemmer, K., and Ahrendt, H.: Exhumation and deformation history of the lower crustal section of the Valstrona di Omegna in the Ivrea Zone, Southern Alps, Geol. Soc. London. Sp. Publ., 298, 45-68, 2008.

Sills, J. D.: Granulite facies metamorphism in the Ivrea zone, NW Italy, Schweiz, Miner. Petrog., 64, 169-191, 1984.

Sinigoi, S., Quick, J. E., Demarchi, G., and Klötzli, U.: The role of crustal fertility in the generation of large silicic magmatic systems triggered by intrusion of mantle magma in the deep crust, Contrib. Mineral. Petr., 162, 691-707, 2011.

Söderlund, P., Söderlund, U., Möller, C., Gorbatschev, R., and Rodhe, A.: Petrology and ion microprobe U-Pb chronology applied to a metabasic intrusion in southern Sweden: A study on zircon formation during metamorphism and deformation, Tectonics, 23, TC5005, https://doi.org/10.1029/2003TC001498, 2004.

Taylor-Jones, K. and Powell, R.: Interpreting zirconium-in-rutile thermometric results, J. Metamorph. Geol., 33, 115-122, 2015.

Thompson, A. B.: Mineral reactions in pelitic rocks. II. Calculation of some $P-T-X(\mathrm{Fe}-\mathrm{Mg})$ phase relations, Am. J. Sci., 276, 425-454, 1976.

Tomkins, H. S., Powell, R., and Ellis, D. J.: The pressure dependence of the zirconium-in-rutile thermometer, J. Metamorph. Geol., 25, 703-713, 2007.

Tromans, D.: Solubility of crystalline and metamict zircon: A thermodynamic analysis, J. Nucl. Mater., 357, 221-233, 2006.

Tuccillo, M. E., Essene, E. J., and van der Pluijm, B. A.: Growth and retrograde zoning in garnets from high-grade metapelites: Implications for pressure-temperature paths, Geology, 18, 830 842, 1990.

Vavra, G., Gebauer, D., Schmid, R., and Compston, W.: Multiple zircon growth and recrystallization during polyphase Late Car- 
boniferous to Triassic metamorphism in granulites of the Ivrea zone (Southern Alps): An ion microprobe (SHRIMP) study, Contrib. Mineral. Petr., 122, 337-358, 1996.

Watson, E. B. and Harrison, M. T.: Zircon saturation revisited: temperature and composition effects in a variety of crustal magma types, Earth Planet. Sc. Lett., 64, 295-304, 1983.

Watson, E. B., Wark, D. A., and Thomas, J. B.: Crystallization thermometers for zircon and rutile, Contrib. Mineral. Petr., 151, 413433, 2006.

Wu, Y.-B., Zheng, Y.-F., Zhao, Z.-F., Gong, B., Liu, X., and Wu, F.$\mathrm{Y}$.: $\mathrm{U}-\mathrm{Pb}, \mathrm{Hf}$ and $\mathrm{O}$ isotope evidence for two episodes of fluidassisted zircon growth in marble-hosted eclogites from the Dabie orogeny, Geochim. Cosmochim. Acta, 70, 3743-3761, 2006.

Zanetti, A., Mazzucchelli, M., Rivalenti, G., and Vannucci, R.: The Finero phlogopite-peridotite massif: an example of subductionrelated metasomatism, Contrib. Mineral. Petr., 134, 107-122, 1999.
Zhang, R. Y. and Liou, J. G.: Exsolution minerals from ultrahighpressure rocks, in: Ultra-high pressure metamorphism and geodynamics in collision-type orogenic belts, edited by: Ernst, W. G. and Liou, J. G., Bellwether Publisher for Geological Society of America, Columbia, 216-228, 2000.

Zhao, L., Li, T., Peng, P., Guo, J., Wang, W., Wang, H., Santosh, M., and Zhai, M.: Anatomy of zircon growth in high pressure granulites: SIMS U-Pb geochronology and $\mathrm{Lu}-\mathrm{Hf}$ isotopes from the Jiaobei Terrane, eastern North China Craton, Gondwana Res., 28, 1373-1390, 2015. 